2. To: (Receiving Organization)

Project Development/Implementaton

5. Proj./Prog./Dept./Div.:

TWRS

8. Originator Remarks:

Please review and approve the attached Interface Control Document

for transfer of waste from T-Plant to Double Shell Tanks

11. Receiver Remarks:

\author{
3. From: (Originating Organization) \\ Project Definition \\ 6. Design Authority/Design Agent/Cog. Engr.: \\ Thomas H. May
}

\author{
4. Related EDT No \\ 625287 \\ 7. Purchase Order No. \\ $\mathrm{N} / \mathrm{A}$ \\ 9. Equip./Component No:: \\ $\mathrm{N} / \mathrm{A}$ \\ 10. System/B/dg./Facility: \\ 204-AR/DST/T-Plant
}

12. Major Assm. Dwg. No.:

13. Permit/Permit Application No::

$N / A$

14. Required Response Date:

$\theta / 06 / 99$

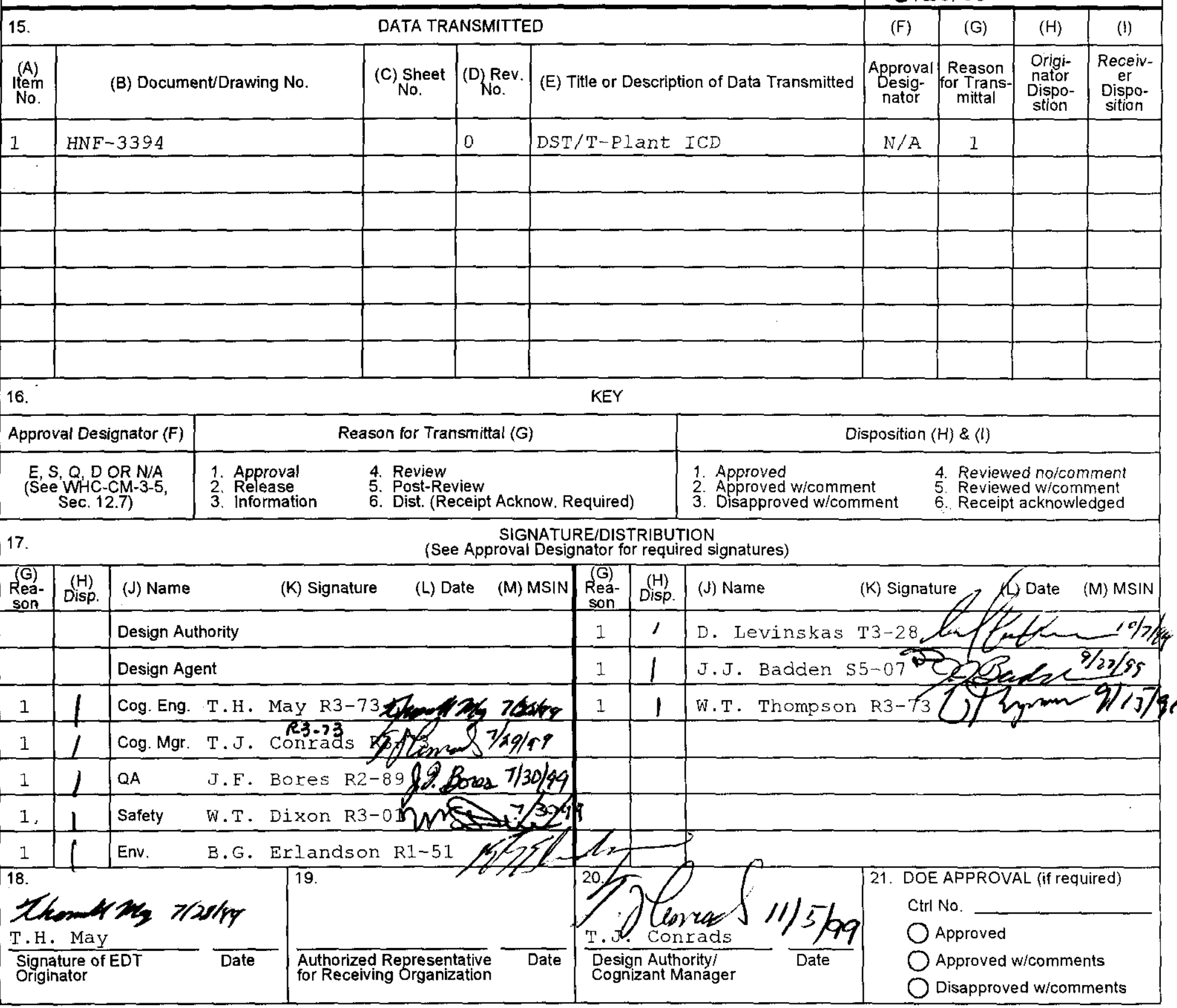

BD-7400-172-2(10/97)

BD-7400-172-1 
Continuation sheet for EDT 625289

Signature/Distribution

$$
2 z^{2}
$$

\begin{tabular}{|c|c|c|c|}
\hline Reason & $\begin{array}{l}\text { Dispo- } \\
\text { sition }\end{array}$ & Name & MSIN \\
\hline 3 & & T. B. Veneziano & S7-40 \\
\hline 3 & & H. L. Boston & R2-53 \\
\hline 3 & & D. I. Allen & $\mathrm{R} 2-50$ \\
\hline 3 & & M. A. Payne & $R 2-58$ \\
\hline 3 & & M. D. Ebben & $\mathrm{H} 7-07$ \\
\hline 3 & & E. E. Mayer & R2-50 \\
\hline 3 & & J. E. Ferguson & $\mathrm{H} 8-71$ \\
\hline 3 & & S. D. Brumley & H7-07 \\
\hline 3 & & R. F. Wood & H7-07 \\
\hline 3 & & R. L. Treat & R3-75 \\
\hline 3 & & R. W. Powell & R3-75 \\
\hline 3 & & R.W. Root & R2-58 \\
\hline 3 & & C. J. Rice & $\mathrm{R} 2-53$ \\
\hline 3 & & R. A. Dodd & R3-72 \\
\hline 3 & & A. F. Choho & R3-73 \\
\hline 3 & & D. M. Hammond & R1-44 \\
\hline 3 & & R. D. Potter & R3-73 \\
\hline 3 & & E. W. Dunbar & K8-95 \\
\hline 3 & & S. M. O'Toole & $\mathrm{R} 2-89$ \\
\hline 3 & & T.M. Blaak & $S 5-13$ \\
\hline 3 & & D.G. Baide & S5-05 \\
\hline 3 & & D.J. Carrell & $\mathrm{R} 1-51$ \\
\hline 3 & & T.J. Conrads & $\mathrm{R} 3-73$ \\
\hline 3 & & C. Defigh-Price & $\mathrm{R} 2-12$ \\
\hline 3 & & B.G. Erlandson & $\mathrm{R} 1-51$ \\
\hline 3 & & K.D. Fowler & $\mathrm{R} 2-11$ \\
\hline 3 & & C.E. Grenard & R3-74 \\
\hline 3 & & G.A. Hofferber & B $1-45$ \\
\hline 3 & & N.W. Kirch & $\mathrm{R} 2-11$ \\
\hline 3 & & T. Laney & S5-05 \\
\hline 3 & & M.W. Leonard & B1-45 \\
\hline 3 & & C.H. Mulkey & $\mathrm{R} 1-5.1$ \\
\hline 3 & & O.D. Nelson & R3-74 \\
\hline 3 & & K. Kover & $\mathrm{T} 4-05$ \\
\hline 3 & & D. Levinskas & $\mathrm{T} 3-28$ \\
\hline 3 & & R.B. Barmettlor & $T 3-28$ \\
\hline 3 & & J.B. Buckley & $T 4-05$ \\
\hline 3 & & T.L. Moore & $\mathrm{Gl}-32$ \\
\hline
\end{tabular}




\title{
Interface Control Document Between the Double Shell Tanks (DST) System and T-Plant
}

\author{
Thomas H. May \\ Numatec Hanford Company \\ Richland, WA 99352 \\ U.S. Department of Energy Contract DE-AC06-96RL13200 \\ EDT/ECN: 625289 \\ UC: $N / A$ \\ Org Code: UF130000 \\ Charge Code: 106462 \\ B\&R Code: N/A \\ Total Pages: \\ $8+11.5+2$
}

Key Words: Interface Control Document, ICD, T-Plant, Double Shell Tanks, DST

Abstract: N/A

TRADEMARK DISCLAIMER. Reference herein to any specific commercial product, process, or service by trade name trademark, manufacturer, or otherwise, does not necessarily constitute or imply its endorsement, recommendation, or favoring by the United States Government or any agency thereof or its contractors or subcontractors.

Printed in the United States of America. To obtain copies of this document, contact: Document Control Services, P.O. Box 950, Mailstop H6-08, Richland WA 99352, Phone (509) 372-2420; Fax (509) 376-4989.
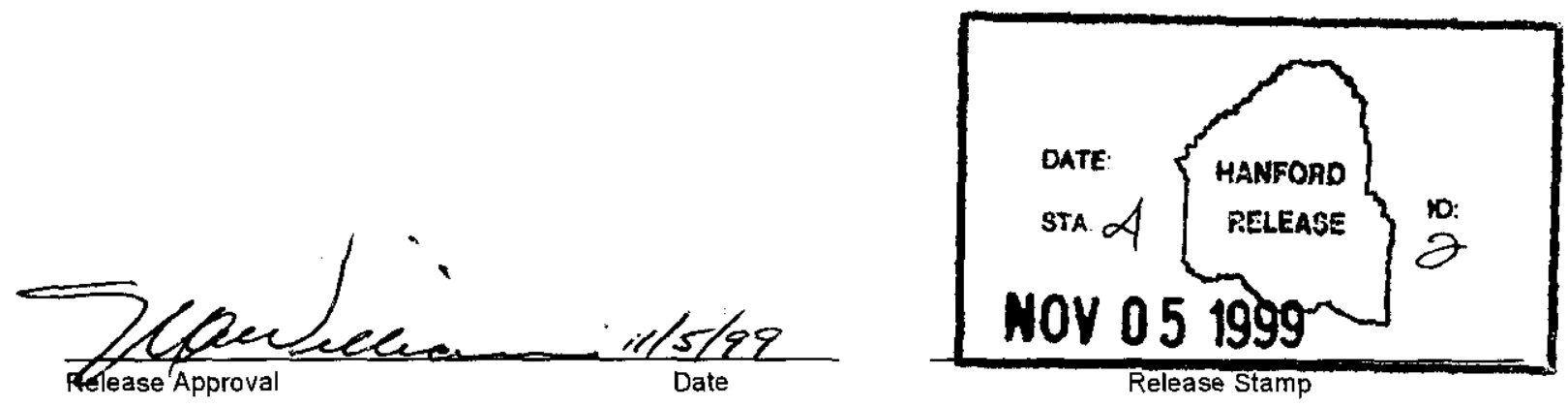

Approved For Public Release 
HNF-3394, Rev 0

\section{Interface Control Document Between the}

Double Shell Tank (DST) System

and T-Plant

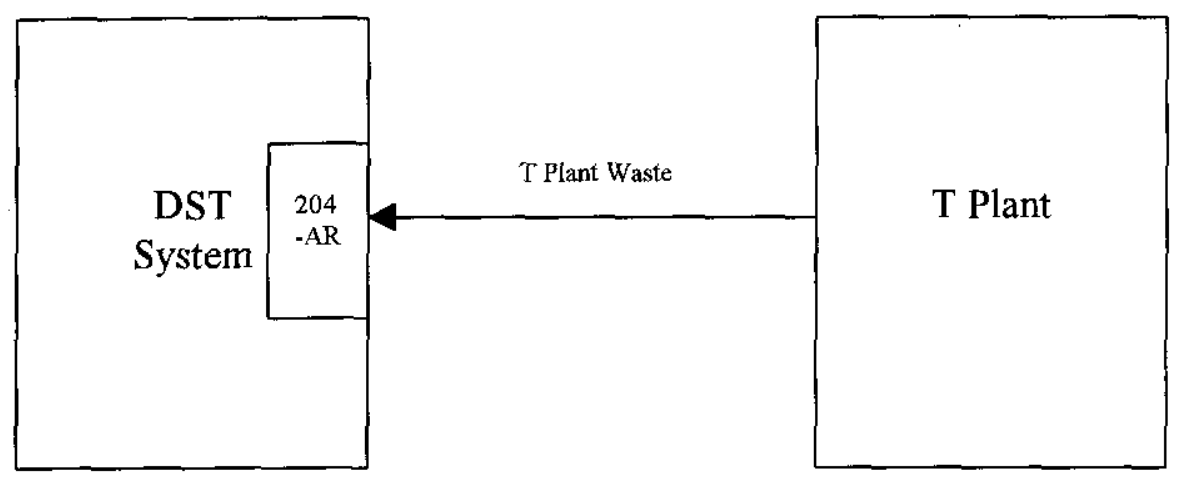

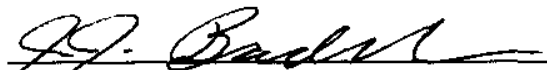

Tank Farm Facility Operations

J. J. Badden

D. Levinskas

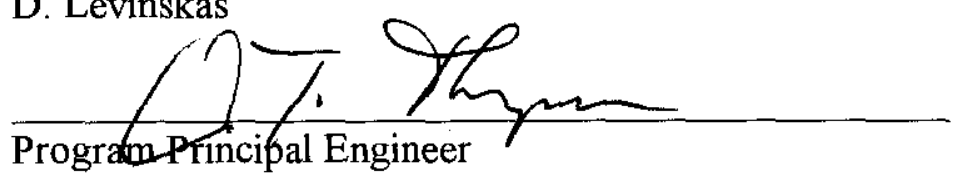

W. T. Thompson
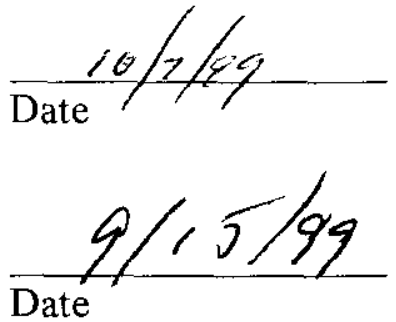
HNF-3394

Revision 0

This page intentionally left blank. 
HNF-3394

Revision 0

\section{CONTENTS}

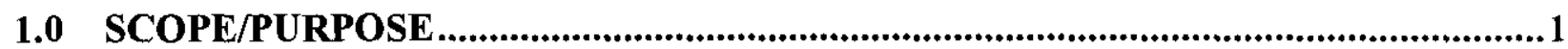

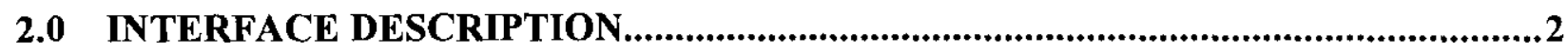

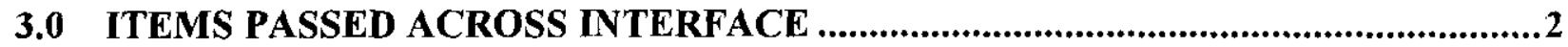

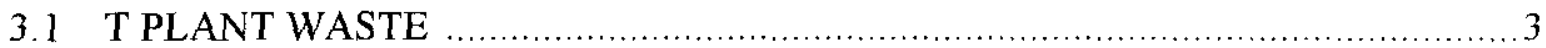

3.1.1 Maximum T Plant Waste Volume ...................................................... 3

3.1.2 T Plant Waste Acceptance into the Double-Shell Tank System ...................... 3

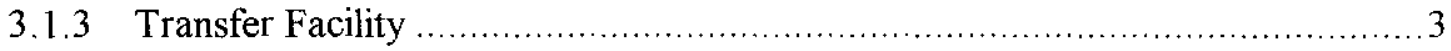

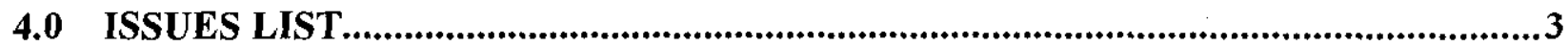

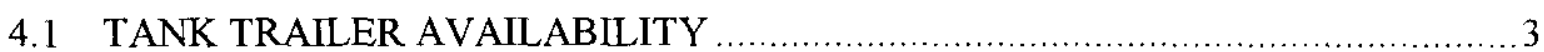

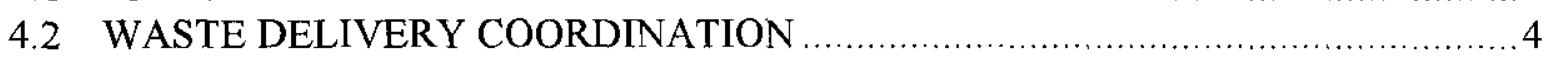

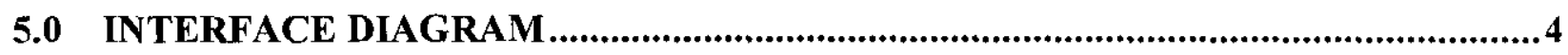

5.1 MC312 TANK TRAILERS TO 204-AR WASTE UNLOADING FACILITY .........4

5.2 MC-312 TANK TRAILER TO T PLANT .................................................. 4

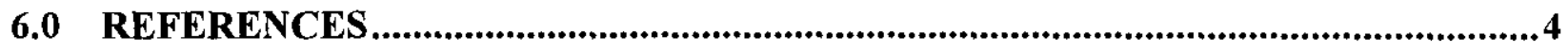

6.1 REFERENCE DOCUMENTS .............................................................. 4

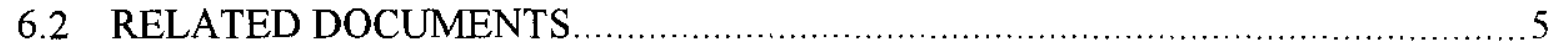


HNF-3394

Revision 0

TERMS

$\begin{array}{ll}\text { DST } & \text { Double-shell tank } \\ \text { FFTF } & \text { Fast Flux Test Facility } \\ \text { HSTD } & \text { Hanford Site Technology Database } \\ \text { ICD } & \text { Interface Control Document } \\ \text { Kgal } & \text { Kilogallons } \\ \text { RPP } & \text { River Protection Project } \\ \text { SST } & \text { Single-shell tank }\end{array}$


HNF-3394

Revision 0

\section{INTERFACE CONTROL DOCUMENT FOR THE DOUBLE-SHELL TANK SYSTEM AND T PLANT}

\subsection{SCOPE/PURPOSE}

This Interface Control Document (ICD) describes the interface between the Double-Shell Tank (DST) System and T Plant. T Plant generates waste during decontamination activities. These facilities do not have a direct physical interface since the waste will be moved by tank trailer to the 204-AR waste unloading facility.

The purpose of the ICD process is to formalize working agreements between the River Protection Project (RPP) DST System and organization/companies internal and external to RPP. This ICD has been developed as part of the requirements basis for design of the DST System to support the Phase I Privatization effort.

The signatures on the cover page of this document indicate agreement between the parties that this document reflects the current technical baseline for each system and that the requirements contained in this document will not be revised without the agreement of all parties.

Figure 1. Interface Control Between the Double-Shell Tank System and T Plant.

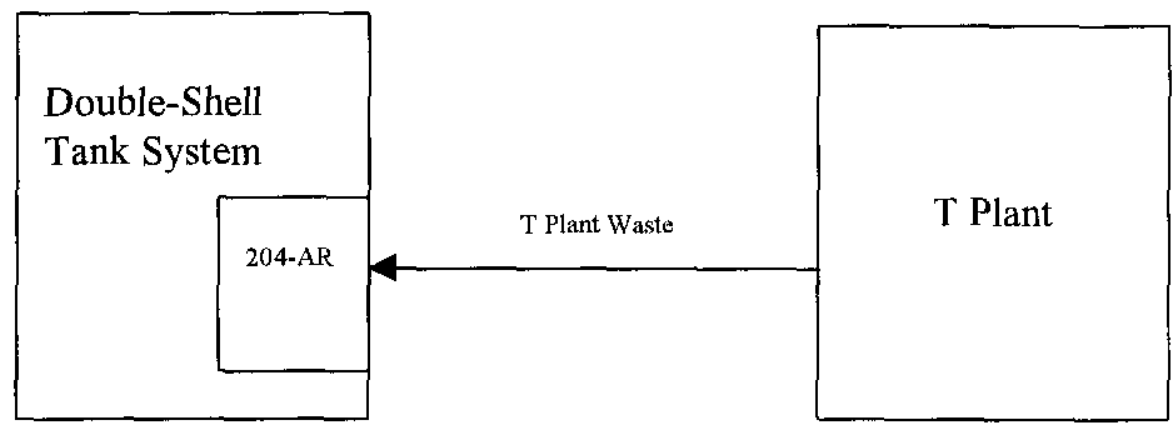


HNF-3394

Revision 0

\subsection{INTERFACE DESCRIPTION}

T Plant will utilize a regulated tank trailer to move waste to the DST System. The tank trailer will be one of three managed by DyCorp, all of which dre designated as MC312. The waste will be transferred from the tank trailer at the 204-AR waste unloading facility. T Plant will coordinate the selection and scheduling of the specific tank trailer to be used for each shipment.

This ICD defines the functional interface and requirements regarding the amount, timing and properties of the waste planned to be delivered to the DST system as a result of T Plant operations and clean out.

T Plant's primary mission is decontamination and treatment of radiologically and chemically contaminated waste and equipment located throughout the Hanford Site. T Plant also provides inspection and repackaging services to various Hanford facilities. The 2706-T Low Level Decontamination Facility is an approved decontamination facility that commenced operation in September 1994. Limited 221-T canyon decontamination activities (primarily Tank Farm long length contaminated equipment) were initiated in 1995.

Dilute, non-complexed waste collected at T Plant during decontamination and condensate collection is currently being transported to 204-AR waste unloading facility via tank trailer. T Plant also may be used to repackage waste from such sources as the Fast Flux Test Facility (FFTF), Quanterra, or Tank Farm samples returned from Savannah River Site and transship the waste to the 204-AR waste unloading facility.

\subsection{ITEMS PASSED ACROSS INTERFACE}

This section contains the item descriptions and interface requirements associated with each item passed across the interface as defined in Section 2.0 above. These interface requirements are intended to be bounding requirements for design purposes. For current operational estimates of waste volumes and timing, refer to the most recent revision of the Operational Waste Volume Projection (Strode 1999). All waste transfers shall comply with the controls contained in the BIO and Technical Safety Requirements (Jones 1999a, b). Specifically, waste transfers shall comply with Adminstrative Control 5.12 "Transfer Controls".

\subsection{T PLANT WASTE}

Waste retrieved from T Plant that is transferred to DST System. 
HNF-3394

Revision 0

\subsubsection{Maximum T Plant Waste Volume}

The DST system shall accept up to $10.2 \mathrm{~m}^{3}(2.7 \mathrm{kgal})$ per month of T Plant waste provided that the waste meets the conditions specified in the compatibility assessment which has been issued recommending acceptance of the waste stream (Strode 1999).

\subsubsection{T Plant Waste Acceptance into the Double-Shell Tank System}

T Plant waste shall comply with the established DST waste acceptance. Specific approval of each waste shipment will be given when conditions in a Compatibility Assessment, issued for that waste stream, have been met. As required by the waste analysis plan, T Plant shall supply waste transfer documentation with each waste transfer to the 204-AR waste unloading facility, including documentation of wastes not generated at $\mathrm{T}$ Plant.

Additionally, T Plant waste chemical and radionuclide compositions shall meet the acceptance requirements contained in the Operating Specification for the 204-AR Waste Unloading Facility (PHMC 1998) before the waste can be received at the 204-AR waste unloading facility.

\subsubsection{Transfer Facility}

The DST System shall maintain the capability to interface with the Hanford site MC312 designated tank trailers at the 204-AR waste unloading facility to accept the T Plant waste as defined in 3.1.1 and 3.1.2.

\subsection{ISSUES LIST}

The following issues do not affect this ICD at this time, but may affect the ICD when they are resolved.

\subsection{TANK TRAILER AVAILABILITY}

One MC312 designated tank trailer, H064-4275, contained waste that was believed to be contaminated with TSCA regulated PCBs. This tank trailer contents have been reviewed and a Certification of Conformance was issued stating the waste is not TSCA regulated (Buckley 1999). Availability of this particular tank trailer should be addressed. 
HNF-3394

Revision 0

\subsection{WASTE DELIVERY COORDINATION}

The 204-AR waste unloading facility receives waste from a number of sources including T Plant, Building 325 , and Building 324 . Waste may also be received from other sources such as WESF. Since the 204-AR waste unloading facility can receive only one truck at a time, delivery of waste from these sources must be scheduled and coordinated.

\subsection{INTERFACE DIAGRAM}

This section provides 'roadmap' to lower level ICDs that have been, or will be, developed to define and control the specific physical interfaces and interface requirements between specific elements of the DST system and T Plant.

For this interface, there are no lower level ICDs. However, the physical interfaces between the sites MC312 tank trailers and both the 204-AR waste unloading facility as well as the T Plant subsystems are discussed here for reference.

\subsection{MC312 TANK TRAILERS TO 204-AR WASTE UNLOADING FACILITY}

The current baseline is to use one of the MC312 tank trailers. The unloading facility has been configured to interface with these trailers, however, at present there is not an ICD that controls this interface. Current facility drawings (H-2-71506/7 and H-2-79957) support transfers using this trailer. Requirement 3.1.3 of this ICD requires that this capability be retained. Tank Farm procedure T0-290-120 details waste unloading from a tank trailer to the 204-AR waste unloading facility.

\subsection{MC-312 TANK TRAILER TO T PLANT}

The interfaces between the MC312 designated tank trailers and T Plant are defined in internal T Plant documents.

\subsection{REFERENCES}

\subsection{REFERENCE DOCUMENTS}

Buckley, J. B., 1999, Waste Transfer Documentation for Shipment Number 99-0I of Waste Encapsulation and Storage Facility Liquid Waste, Letter to C. B. Bryan, WMH-9951979 (March 29), Waste Management Hanford, Richland, Washington. 
HNF-3394

Revision 0

Fowler, K. D., 1995, Tank Farm Waste Transfer Compatibility Program, WHC-SD-WM-OCD-015, Rev. 1, Westinghouse Hanford Company, Richland, Washington.

Mulkey, C. H., 1998, Double Shell Tank System Waste Analysis Plan, HNF-SD-WM-EV-053, Rev 5, Lockheed Martin Hanford Corporation, Richland, Washington.

PHMC, 1998, Operating Specification for the 204-AR Waste Unloading Facility, OSD-T-151-0008, Rev. E-3, Project Hanford Management Contractor, Fluor Daniel Hanford, Inc., Richland, Washington.

Strode, J. N., 1998, Operational Waste Volume Projection, HNF-SD-WM-ER-029, Rev. 24, Lockheed Martin Hanford Corporation, Richland, Washington.

\subsection{RELATED DOCUMENTS}

Grenard, C. E., 1998, System Specification for the Double Shell Tanks System, HNF-SD-WM-TRD-007, Rev. E, Cogema Engineering, Richland, Washington.

PHMC, 1999a, Tank Farms Operations Administrative Controls, HNF-IP-1266, Rev. 0, Lockheed Martin Hanford Corporation, Richland, Washington

Mayer, E. E., \#80232764-9-K001-Revised Double-Shell Tank Waste Acceptance Criteria, External letter LMHC-9757070 to A. M. Umek (August 12, 1997), Lockheed Martin Hanford Corporation, Richland, Washington.

PHMC, 1999b, Data Quality Objectives for the Waste Compatibility Program, HNF-SD-WMDQO-001, Rev. 3, Lockheed Martin Hanford Corporation, Richland, Washington.

Wicks, J. H., Subcontract Number, Configuration Control of Tank Waste Compositions, External Letter LMHC-9755448 to W. M. Funderburke (June 20, 1997), Lockheed Martin Hanford Corporation, Richland, Washington.

Mayer, E. E., \#80232764-9-K001-Revised Waste Acceptance Criteria, External Letter LMHC9754635 to A. M. Umek (June 12, 1997), Lockheed Martin Hanford Corporation, Richland, Washington.

Fowler, K. D., 1995, Tank Farm Waste Compatibility Program, WHC-SD-WM-OCD-015, Rev. 1, Lockheed Martin Hanford Corporation, Richland, Washington.

PHMC, 1999c, Tank Farm Plant Operating Procedure 204-AR Unloading Facility Transfers TO-290-052, Rev. C-4, Lockheed Martin Hanford Corporation, Richland, Washington. 